\title{
ANALISIS FILM ARTIFICIAL INTELLIGENCE (AI) PADA ASPEK SOSIAL, KULTURAL DAN TEKNOLOGI
}

\author{
Marsefio S. Luhukay \\ Jurusan Ilmu Komunikasi, Fakultas Ilmu Komunikasi \\ Universitas Kristen Petra \\ Jalan Siwalankerto 121-131, Surabaya 60235 \\ email: ashandy@peter.petra.ac.id
}

\begin{abstract}
Why do we have such interest in analyzing a movie? Because movie is interesting and, yet, ambiguous. On one side, a movie is rich with elements of postmodernism. On the other side, movie is filled with real representation of social realities that occurred in real world; where human unable to accept it limitation, humanity. Because, there are certain things that human should not do. Humans endured in themselves the emotions which add complexities in meeting their problems. Whilst, robots have none. Robot is efficient and as a machine it has a great power that humans do not possess.

Humans desire for robots in this world, because humans need to gain control. There is a wanting for taking control on their fellow humans. If, that can be done, then there will be wars of interest, enmity, conflicts, and so on. But, if, in some way, robots are the object of control, everything will be different. Robots controlled by humans, and humans handle the remote control or the chip.
\end{abstract}

Keywords: film, social aspect, cultural, technology

\section{PENDAHULUAN}

Dalam masa mendatang ketika es di kutub mencair akibat pemanasan global, dan menyebabkan naiknya permukaan laut, menenggelamkan semua kota di tepi pantai di dunia. Ras manusia menjadi makin sedikit. Karena kebutuhan mengelola bumi, diperlukan bantuan robot. Pada saat itu, manusia telah mencapai suatu titik dalam menciptakan robot yang realistic (hampir Mirip dengan manusia) yang disebut Mecha. Robot-robot ini diciptakan untuk melayani manusia. Tetapi keterbatasan robot-robot ini adalah mereka menyerupai manusia dalam segala hal, tetapi mereka tidak memiliki hati/perasaan seperti manusia. Karena itu, salah satu perusahaan yang memproduksi Mecha, menciptakan David, seorang anak tiruan pertama berusia 11 tahun, yang memiliki perasaan sesungguhnya. Ia di"disain" untuk bagaimana mencintai dan memahami perasan manusia. Terutama ia memiliki cinta yang sangat mendalam pada "ibunya" Monica. Monica adalah seorang wanita yang mengadopsi David sebagai pengganti anak kandungnya yang sedang dalam keadaan koma, akibat penyakit yang tak bisa disembuhkan. David hidup bahagia bersama "Ibu dan ayahnya" (Monica dan suaminya). Tetapi hidupnya mendadak berubah dramatis ketika anak kandung Monica menjadi sembuh dan 
pulang kembali ke rumahnya. Macam-macam masalah mulai timbul akibat rasa iri yang ada dalam diri Michael anak kandung Monica.

Adaptasi futuristic yang diinspirasi oleh cerita Pinokio yang mendambakan bagaimana ia menjadi nyata, menjadi manusia sesungguhnya yang layak mendapat cinta kasih dari orang tua dan manusia lain disekitarnya.

Dalam cerita futuristic ini, David sang robot kecil yang canggih ini, sangat mendambakan menjadi anak lelaki yang sesungguhnya. Supaya ia dapat memenangkan kembali cinta kasih "ibu" nya yang adalah seorang manusia. Selanjutnya adalah perjalanan David mencari "ibu"nya dan akhirnya bertemu dengan seorang Mecha "Joe" yang adalah gigolo yang tadinya bersifat sangat dingin (tentu, karena ia cyborg juga) akhirnya bisa bersahabat dan mereka menemukan jati diri mereka masingmasing.

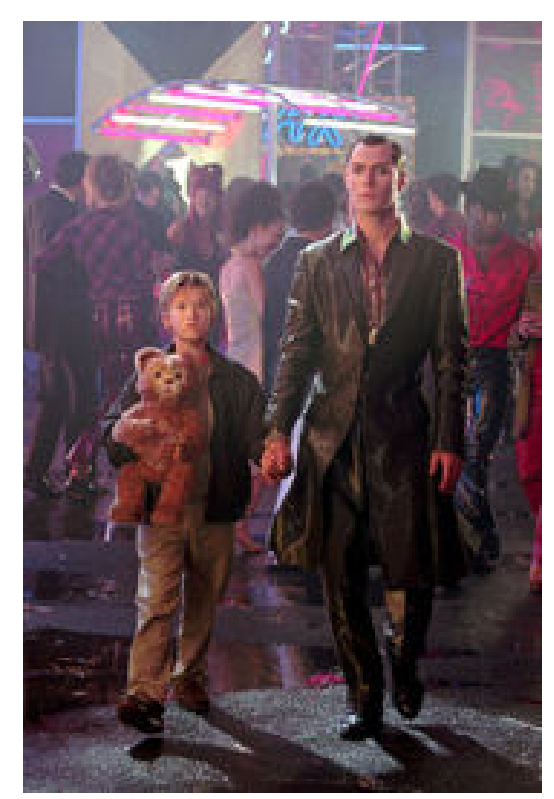

Sumber: Film Artificial Intelligence

\section{Gambar 1. Persahabatan antara si Robot Cilik David (Halley Joel Osment) dan Gigolo Joe (Jude Law)}

\section{PEMBAHASAN}

Film adalah salah satu bentuk karya seni yang menjadi fenomena dalam kehidupan modern, setelah ditemukannya media untuk mengapresiasikannya. Sebagai salah satu objek seni abad ini, film dalam prosesnya berkembang menjadi salah satu bagian dari kehidupan sosial, yang tentunya memiliki pengaruh yang cukup signifikan pada manusia sebagai penonton. Hal ini sesuai dengan apa yang dikatakan oleh Sumarno. Menurut Sumarno (1998:85), film adalah sebuah seni mutakhir dari abad 20 yang dapat menghibur, mendidik, melibatkan perasaan, merangsang pemikiran dan memberikan dorongan terhadap penontonnya.

Dunia film, pada dasarnya juga sebagai bentuk pemberian informasi kepada masyarakat. Film juga memiliki kebebasan dalam menyampaikan informasi atau 
pesan-pesan dari seorang pembuat sineas kepada penontonnya. Kebebasan dalam hal ini adalah film, sering secara lugas dan jujur menyampaikan sesuatu, di pihak lain film juga terkadang malah disertai dnegan tendensi tertentu, misalnya ingin mendeskripsikan suatu tema sentral. Berdasarkan maksud ingin memberikan informasi, secara umum film dikelompokkan menjadi dua pembagian besar yaitu film cerita dan non cerita. Film cerita adalah film yang menyajikan kepada publik sebuah cerita dan mengandung unsur-unsur yang menyentuh rasa manusia. Film yang bersifat auditif visual, yang dapat disajikan kepada publik dalam bentuk gambar yang dapat dilihat dengan suara, yang dapat didengar dan yang merupakan suatu hidangan yang sudah masak untuk dinikmati, sungguh merupakan suatu medium yang bagus untuk mengolah unsur-unsur tadi.

Film sendiri mempunyai banyak unsur-unsur yang terkonstruksikan menjadi satu kesatuan yang menarik. Unsur-unsur seks, kejahatan/kriminalitas, roman, kekerasan, rasisme dan sejarah adalah unsur-unsur cerita yang dapat menyentuh rasa manusia, yang dapat membuat publik terpesona, yang dapat membuat publik tertawa terbahak-bahak, menangis terisak-isak, dapat membuat publik dongkol, marah, terharu, iba, bangga, gembira, tegang dan lain-lain. Maka diambillah episode-episode dari kitab injil, kisah-kisah dari sejarah, cerita nyata kehidupan sehari-hari, atau juga khayalan untuk kemudian diolah menjadi sebuah film (Effendy, 2003:212)

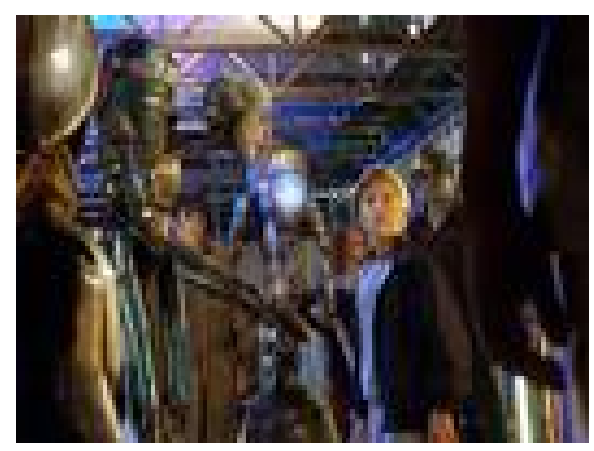

Sumber: Film Artificial Intelligence

Gambar 2. Upaya David mencari Monica, sang "Ibu"

\section{KONSEP ARTIFICIAL INTELLIGENCE}

Terminologi Artificial Intelligence (AI) ini dimunculkan pertama kali oleh John McCarthy (is a prominent computer scientist who received the Turing Award in 1971 for his major contributions to the field of Artificial Intelligence) http://en.wikipedia. org/wiki/John_McCarthy_\%28computer_scientist\%29 yang menyebutkan istilah AI untuk menunjukkan bahwa "ilmu pengetahuan dan rekayasa teknik dapat membuat mesin-mesin yang pandai. AI bisa juga mengacu pada kepandaian yang ditunjukkan oleh suatu bentuk tiruan (buatan manusia/hasil karya manusia, tidak alami, diproduksi secara besar-besaran/massal) Ketika AI diterima sebagai terminology umum, termasuk didalamnya kepandaian komputerisasi dan kepandaian sintetik (tiruan), telah diakui sebagai sesuatu yang potensial yang lebih akurat (dibanding kemampuan manusia biasa). Istilah kuat dan lemah AI dapat digunakan untuk 
mempersempit definisi yang mengklasifikasikan sistem tersebut. AI dipelajari disemua bidang ilmu seperti computer science, psikologi, filsafat, neuroscience dan teknik mesin, yang berhubungan dengan kepandaian perilaku (behavior), pembelajaran, dan adaptasi dan biasanya dikembangkan menggunakan mesin atau computer yang canggih. http://en.wikipedia.org/wiki/Artificial_intelligence

Sebagai Science Fiction (Fiksi ilmiah), AI umumnya digambarkan sebagai kekuatan akan datang yang mencoba untuk menggeser otoritas atau kekuasaan manusia. Seperti suatu masyarakat (society) yang dikontrol oleh komputer yang super, dan bahkan manusia masa depan justru yang akan melayani para robot. Kedepan, akan ada pilihan yang menggambarkan peradaban dunia yang dapat memilih untuk diatur oleh AI atau meniadakan AI sama sekali. Contoh AI dalam dunia nyata adalah "Deep Blue" Chess playing computer pertama yang menang melawan pecatur dunia Garry Kasparov tanggal 10 Februari 1996. Ini merupakan bukti bahwa AI bisa nyata dalam dunia sesungguhnya. Penulis (author) yang benyak menulis tentang scence fiction dan mereka mempercayai bahwa suatu saat AI akan mendominasi dunia adalah: Kevin Warwick, Hans Moravec and Isaac Asimov.

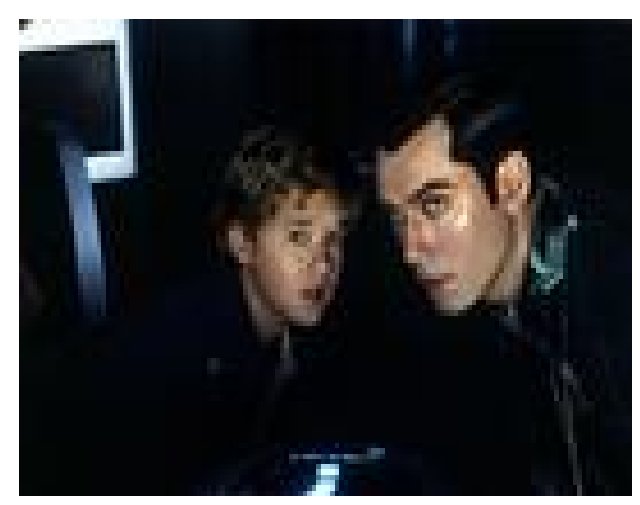

Sumber: Film Artificial Intelligence

\section{Gambar 3. David dan Gigolo Joe}

\section{KONSEP CYBORG}

Menurut Donna Haraway, cyborg adalah sebuah mekanisme sibernetik, suatu perpaduan antara mesin dan organisme, ciptaan dari realitas social dan juga rekaan fiksi. Realitas social hidup dalam hubungan social, konstruksi politik kita yang paling penting. Suatu fiksi tentang dunia yang berubah. Dona mencontohkan gerakan wanita secara global telah membentuk "pengalaman wanita". Pengalaman ini merupakan suatu bentuk fiksi dan fakta diantara bentuk-bentuk politik yang krusial.

Cyborg adalah organisme sibernetik perpaduan dari makhluk hidup (organisme dan mesin). Cyborg bukan saja mengenai Mesin dan Manusia, sama seperti Benda dan Subjek yang ada secara universal. Akan tetapi Cyborg berbicara mengenai sejarah tertentu mesin dan manusia dalam hubungan yang seringkali berubah menjadi berseberangan secara intuisi (counter intuitif) yang menyakitkan bagi analis technoscience. (Modest_Witness@ Second_Millennium. FemaleMan@_Meets_Onco- 
Mouse $^{\text {a }}$ Feminism and Technoscience. New York and London: Routledge, 1997. 51) http://www. cyberartsweb.org/cpace/cyborg/haraway/definition.html

\section{ASPEK SOSIAL: CYBORG dan MANUSIA}

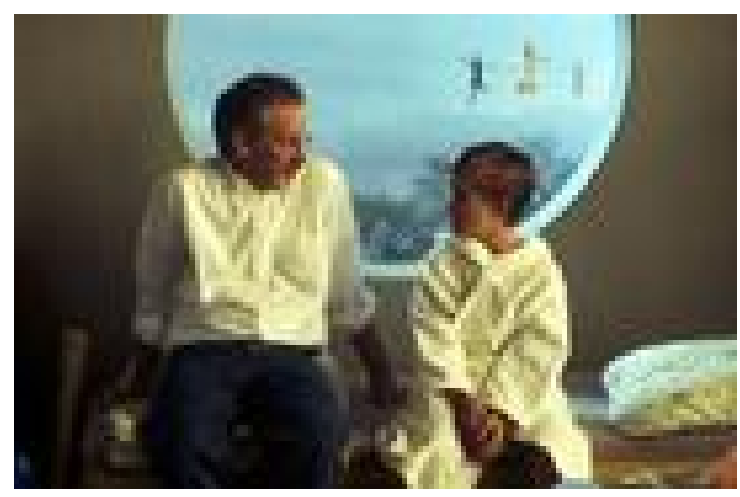

Sumber: Film Artificial Intelligence

\section{Gambar 4. Keinginan David untuk menjadi Anak Manusia yang sesunguh- nya}

Konsep akan perlunya persentase tertentu dalam tubuh manusia untuk memiliki kualitas sebagai manusia memunculkan suatu pertanyaan yang fundamental, yaitu apakah manusia itu? Apakah sama seperti salah satu tokoh protagonist dalam film-film science fiction (blade runner, terminator, Soldier, dll)?

Ketika tokoh atau karakter bertindak seperti manusia, terlihat seperti manusia, menunjukkan emosi, memiliki kelemahan dan kekuatan, maka penonton akan bersimpati pada tokoh tersebut (David, dalam Artificial Intelligence). Sepertinya kita sebagai penonton memperhatikan siapapun tokoh yang mengingatkan mereka akan diri kita sendiri.

Sebaliknya karakter tokoh yang antagonist memiliki kualitas yang diasosiasikan dengan mesin yaitu tidak memihak dan penuh perhitungan (contohnya Caine 607 dalam Soldiers) Dengan demikian kriteria utama untuk dianggap sebagai manusia adalah seberapa banyak tokoh tersebut terlihat seperti manusia lainnya atau seberapa baik mereka menunjukkan kualitas-kualitas kemanusiaan mereka.

Secara Ilmiah, manusia didefinisikan sesuai dengan ciri-ciri fisik. Manusia adalah salah satu spesies mamalia, homo sapiens berkaki dua, dengan otak bagian depan yang membesar. Namun sama seperti yang ditunjukan dalam film, apa yang menjadi pertimbangan penonton tentang manusia tidak sepenuhnya berhubungan dengan karakter yang dilahirkan oleh manusia lainnya.

Film-film tentang cyborg dan manusia menciptakan suatu ide kemanusiaan berdasarkan aksi atau tindakan dan emosi daripada karakteristik fisik (Lihat film Arificial Intelligence). Ide tentang cyborg tetap didasarkan terutama pada gambaran fisik. Tetapi ada perkecualian yang muncul dalam film AI ini. Tokoh "Joe" dan David digambarkan sebagai Cyborg yang memiliki fisik sempurna dan nyaris sama seperti manusia. 
Mungkin tidak pernah kita membayangkan mesin sebagai perpanjangan dari tubuh kita dan mempertimbangkan hubungan kita dengan mesin lebih penting daripada perbedaan antara kita dengan mereka. Kita melihat hubungan antara manusia dan mesin (Cyborg) sebagai suatu integrasi. Dalam beberapa film kita melihat mesin yang digabungkan dengan tubuh (David, Robo-COP, Terminator) atau bahkan menanamkan mesin dalam tubuh (Johnny mnemonic) dan film lainnya memilih untuk menciptakan tubuh buatan dan memberikan nama yang menarik yakni Robot (IRobot, Transformer) (http://www.cyberartsweb.org/cpace/cyborg/ film/schwartz.html)

\section{ASPEK TEKNOLOGI}

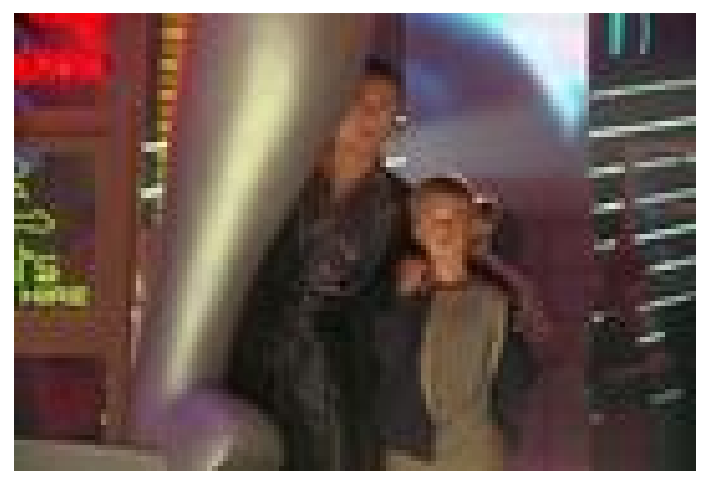

Sumber: Film Artificial Intelligence

\section{Gambar 5. Upaya pencarian David untuk menemukan cinta yang sejati dari seorang "Ibu"}

Aspek teknologi saat ini memungkinkan kita untuk menciptakan robot-robot yang dapat dipelajari melalui perspektif psikologi dan sosial sebagai kesatuan fungsi tindakan. Tujuannya untuk meniru otak yang sangat rumit sehingga robot-robot tersebut bisa menjadi benar-benar pintar. Robot takkan pernah menjadi sama seperti manusia, dikarenakan fakta sederhana bahwa manusia memiliki proses berpikir yang acak dan sering membuat kesalahan. Mesin tak bisa dipaksa untuk berpikir dengan pola yang sama seperti manusia. Demikian juga bahwa cara manusia berpikir dikendalikan oleh perasan mereka. Dan tentunya hal ini tidak dapat dilakukan oleh robot.

Cyborg saat ini eksis. Di Amerika 10\% dari populasinya saat ini diperkirakan adalah "cyborg" dalam arti teknis. Yaitu orang-orang yang menggunakan elektronik pacemaker, tulang sendi tiruan, sistim implantasi obat, impan lensa kornea, kulit tiruan. Persentase yang lebih tinggi berpartisipasi dalam pekerjaan-pekerjaan yang mengubah mereka menjadi "cyborg metaphoric". Termasuk "keyboarder" computer yang disambung sirkuit sybernetic dengan monitor, dokter syaraf yang dituntun oleh microskop optic fiber dalam suatu operasi dan pemain game remaja dalam tokohtokoh video game lainnya.

Scott Bukatman menamainya "terminal identitas" atau "artikulasi ganda yang tak dapat diragukan". Yang mengindikasikan akhir dari konsep tradisional tentang identitas. Bahkan menunjuk pada lompatan sibernetik yang menghasilkan subjektivitas baru. (Katherine Hayles, "The Life of Cyborgs: Writing the Posthuman. "Cyborg Handbook, 322) 
Penggabungan antara konstruktor dan yang dikonstruksikan dalam hal ini menunjuk pada system tubuh yang sekarat dan sirkuit yang hidup, dan sel-sel yang hidup dan tiruan, telah disebut dalam banyak arti: system bionic, mesin-mesin yang vital, cyborg. Mereka adalah tokoh utama akhir abad ke-20, tetapi cerita mengenai cyborg bukan hanya dongeng yang diceritakan di televisi. Dalam masyarakat, banyak terdapat cyborg diantara kita. Siapapun dengan organ tiruan, anggota tubuh atau tambahan (seperti "pacemaker"), siapapun yang diprogram ulang supaya tahan terhadap penyakit (imunisasi) atau obat yang digunakan untuk berpikir/berperilaku/merasa lebih baik (psychopharmacology) secara teknis adalah seorang cyborg. Bukan hanya seperti yang digambarkan dalam film-film seperti AI, RoboCOP, Terminator tetapi bisa jadi orang-orang yang dekat dengan kita yang berada disekitar kita yang menggunakan alat-alat tiruan, sibernetik, dll.

(Chris Hables Gray, Steven Mentor, and Jennifer Figueroa-Sarriera, "Cyborgology: Constructing the Knowledge of Cybernetic Organisms."Cyborg Handbook, 322 dalam http:/www.cyberartsweb.org/cpace/cyborg/haraway/ definition.html

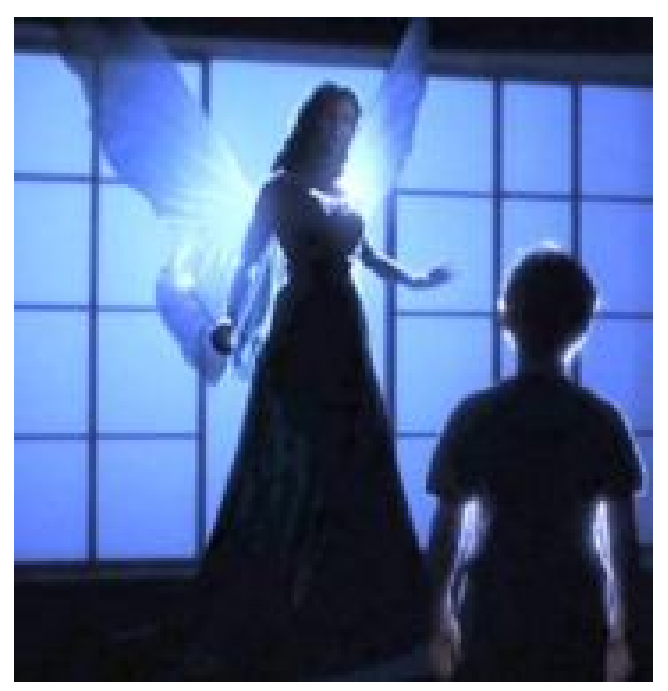

Sumber: Film Artificial Intelligence

\section{Gambar 6. "Peri” yang akan mengabulkan permohonan David}

\section{ANALISA KULTUR}

Film ini adalah film yang diproduksi di Amerika, yang sangat kental dengan nuansa western. Dalam film-film Western kita melihat ada "jagoannya". Tetapi jagoan dalam Film ini berupa cyborg kecil yang canggih bernama David. Kultur western kental dengan futuristic. Kita mengenal film-film yang berbicara tentang cyborg sudah sejak tahun 1920-an. Contohnya The Phantom Empire Tahun 1920 dan juga Robot perempuan mulai muncul pada Metropolis di tahun 1921 .

Tahun-tahun awal televisi di Indonesia mulai muncul, yakni sekitar tahun 1960-an akhir dan awal 1970-an kita melihat ada film-film seperti star trek danjuga ditahun 1980-an awal ada film seperti six million dollar man dan bionic woman. Film-film televisi pada masa itu walaupun televisinya secara teknologi masih hitam putih, tetapi film yang diproduksi sudah sangat futuristik. Ini menggambarkan 
pemikiran orang-orang di dunia barat yang cenderung futuristik, sehingga lahirlah film-film science technology sampai sekarang ini, dan menguasai pasar dunia. Tentunya bagian juga dari power kapitalisme yang menguasai dunia lewat perfilman.

\section{FILM ARTIFICIAL INTELLIGENCE dan POSMODERNISME}

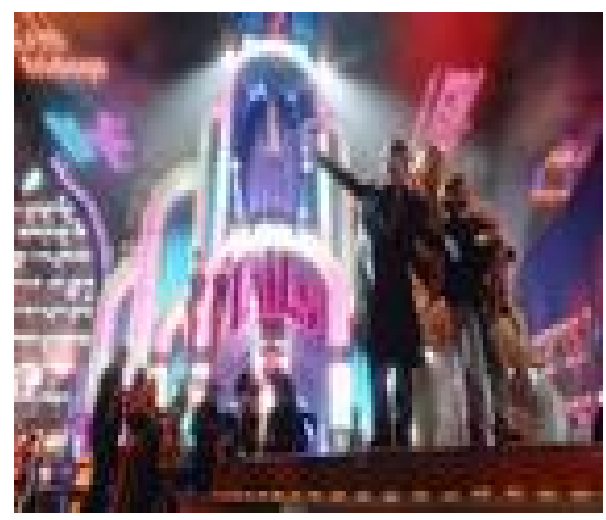

Sumber: Film Artificial Intelligence

\section{Gambar 7. Penggambaran dunia masa depan}

AI adalah film yang kaya akan unsur-unsur Posmodern Argumen-argumen postmodernis jelas-jelas memperhatikan masalah visual, dan film-film yang paling jelas untuk mencari tanda-tanda posmodernisme yang memberi tekanan pada gaya, tontonan, efek dan citraan khusus, dengan mengorbankan isi, karakter, substansi, narasi, dan kritik sosial. (Dominic Strinati, 2000:263) Contoh-contoh film semacam ini selain AI adalah Dick Tracey (1990), Back to the future (1985, 1989 dan 1990). Jika diamati, film semacam ini memang sengaja menghindari realisme dan menjual diri atas kualitas permukaannya bisa jadi mengaburkan sebagian hal lain yang terjadi di dalam film masa kini.

Dalam film Artificial Intelligence ini, Karya dari sang maestro Stephen Spielberg menceritakan tentang dunia dimasa depan (futuristic). Film ini menggambarkan manusia-manusia yang hidup bersama dengan para robot yang canggih. Ciri khas film futuristic Stephen Spielberg menekankan pada tontonan dan aksi melalui penggunaan teknik-teknik yang canggih dan rangkaian usaha yang tak berbelas kasihan, dan bukannya kompleksitas maupun nuansa jalinan alur dan pengembangan karakter. Kadang-kadang dikatakan bahwa tuntutan naratif realisme klasik semakin diabaikan oleh film postmodern (Dominic Strinati, 2000 : 263)

Dalam film ini terlihat Robot-robot, yang ditugaskan untuk melayani manusia, membantu meringankan pekerjaan manusia. Dalam film ini tidak ada robot-robot cybernetic seperti di RoboCOP atau Terminator, dll. Yang memiliki badan kekar, besar, otot kuat seperti baja, yang ada adalah robot-robot yang "manis" yang didisain dengan canggih dan hampir mirip dengan manusia. Yang tampak adalah apa yang dikatakan oleh Dominic Struati sebagai "manusia bukan manusia". Artinya bukan robot mekanis, melainkan "replikan", simulasi manusia yang nyaris sempurna.

Mengapa tertarik menganalisa film ini? Karena saya melihat ada yang menarik dalam film ini yakni muncul ambigu. Di satu sisi, film ini kaya akan unsur-unsur posmodernisme. Tetapi saya melihat juga bagaimana film ini sebagai penggambaran 
(representasi) sesungguhnya atas realitas social yang terjadi. Dimana manusia tidak dapat menerima keterbatasannya, kemanusiaannya, Karena ada hal-hal yang tidak bisa dilakukan semestinya oleh manusia. Manusia memiliki perasaan-perasaan yang membuat ia makin kompleks menghadapi persoalannya. Sebaliknya Robot tidak. Robot sangat efisien dan karena ia mesin, maka ia memiliki kekuatan (power) yang besar, yang tidak dimiliki oleh manusia biasa.

Manusia menginginkan Robot ada didunia ini, karena manusia ingin memegang kendali (power). Ada keinginan untuk menguasai sesamanya. Dan jika hal itu dilakukan pada sesama manusia lain, maka tentu saja yang akan terjadi adalah bentrokan kepentingan dan juga permusuhan, konflik, dll. Tetapi jika yang dikendalikan adalah robot, maka tentu saja hal ini menjadi berbeda. Robot dikendalikan oleh manusia dan manusia yang memegang "remote control atau chipnya". Robot tidak bisa menjadi manusia, ia mempunyai memori, tetapi ia bukan manusia. Secara fisik mungkin bisa mirip sekali, tetapi dan psikis dan biologis ia berbeda (lihat sewaktu David mencoba memakan bayam dan ia ternyata "meleleh" oleh Dokternya, ia dikatakan: "nak, kamu membunuh dirimu sendiri... bayam untuk popeye atau untuk manusia biasa, sedangkan kamu bukan....). Dilihat bagaimana gigihnya upaya David untuk menemukan kembali kasih sayang "ibunya" bahkan ia "rela" menunggu hingga ratusan tahun ketika es mencair dan yang ada dibumi hanya lah alien, David tetap setia menunggu "ibunya". Ini bukti bahwa robot memiliki kesetiaan, setia pada "tuannya" atau manusia yang ia anggap sebagai "tuannya". Tetapi sebaliknya Robot juga bisa balik menyerang manusia jika "ia" merasa manusia mengancam diri manusia sendiri dan melakukan tindakan yang membahayakan manusia, maka tugas robot adalah menyelamatkan manusia tersebut, sesuai dengan order atau perintah yang mereka terima. Robot tidak bisa berkompromi dan fleksibel seperti manusia. (lihat film I-Robot). Manusia memiliki naluri, robot tidak, manusia memiliki keterbatasan, Robot juga, tetapi dengan cepat dapat dipulihkan. Ini contoh film-film Postmodern) Selain itu saya melihat bahwa Robot bisa hidup dalam dunia masa kini, masa lalu bahkan masa depan. Ia memiliki kemampuan seperti itu, yang tidak bisa dipunyai oleh manusia. Manusia hanya bisa hidup hari ini dan masa lalu menjadi bayangan, ketika ia mau melangkah maju, maka masa lalu harus ia tinggalkan, jika tidak maka perasaan manusia itu sendiri akan hancur. Beda dengan robot yang tetap memiliki perasaan masa lalu yang kuat (Perasaan cinta pada "Ibu"nya Tokoh David dalam AI)

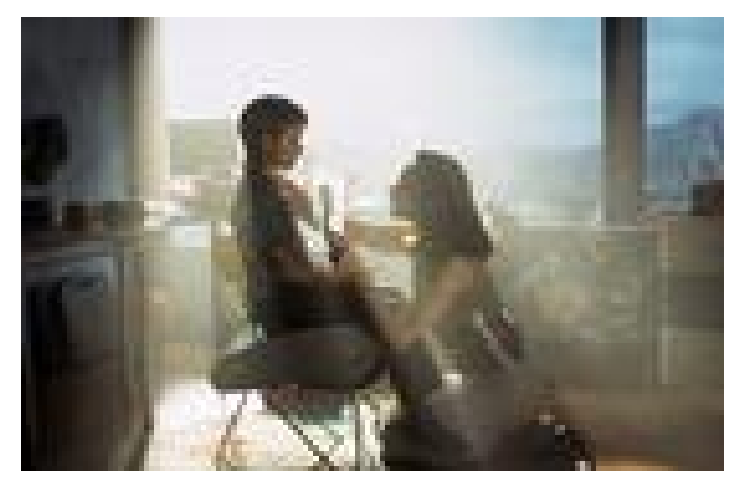

Sumber: Film Artificial Intelligence

\section{Gambar 8. Harapan David untuk dicintai Monica, sang "Ibu" akhirnya terwujud}


Tetapi sebaliknya saya melihat bahwa manusia bisa menjadi "Robot". Ketika robot mengerahkan segenap kemampuannya untuk menjadi manusia, ia tetaplah robot. Tetapi manusia, jika menghilangkan sifat kemanusiaannya dengan menghindari kehidupan social, menutup diri, tidak mau berkomunikasi dengan orang lain maka akan menjadi "Robot" (lihat film Soldiers bagaimana Todd yang diperankan oleh Kurt Russell menjadi tentara Amerika masa depan yang dilatih sejak bayi hingga dewasa lewat latihan mental dan fisik yang keras untuk menjadi mesin pembunuh, dan ia menjadi seperti robot. Tidak dapat bergaul dengan orang lain. Dan selama film yang panjangnya 157 menit itu, ia hanya berbicara 104 kata. Menakjubkan!).

Dalam film artificial intelligence ini saya melihat bagaimana tokoh gigolo "Joe"

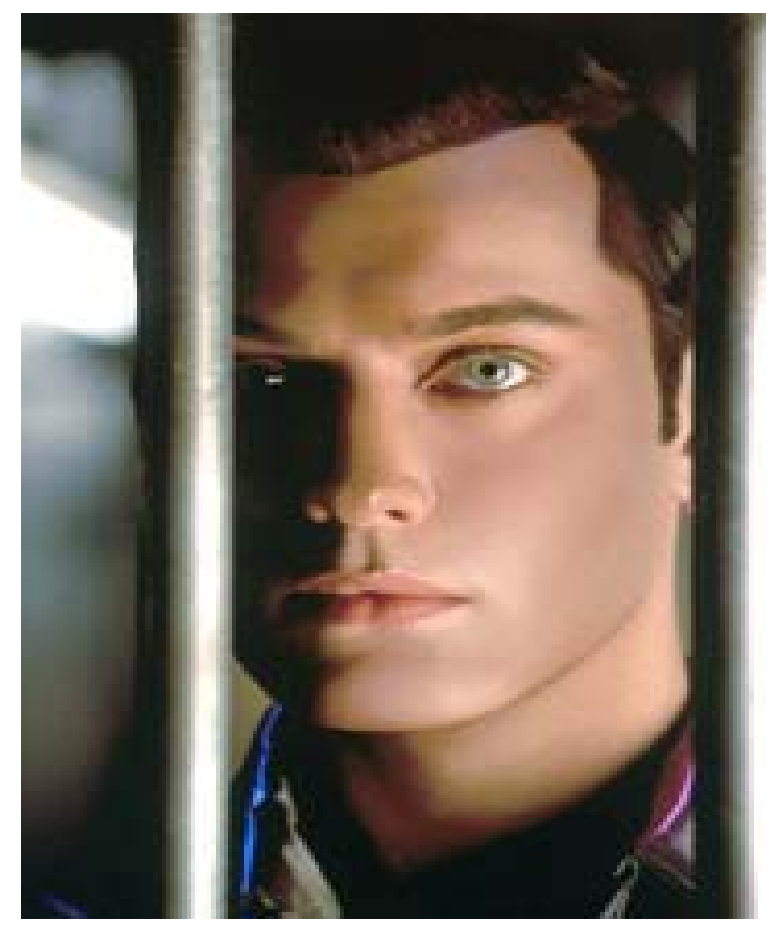

Sumber: Film Artificial Intelligence

\section{Gambar 9. Jude Law yang memerankan tokoh gigolo Joe}

dapat menjadi "mesin pemuas" yang dalam hal ini merupakan bagian dari permainan pikiran sang sutradara Stephen Spielberg. Cyberfantasies. Menurut saya Film ini penuh entertainment yang dituangkan dalam Urban Techno Dystopian. Bagaimana penggambaran kota-kota bawah tanah, bagaimana kota mati akibat air laut yang naik ke permukaan, semua tergambarkan dengan sangat baik dalam film ini. Film ini secara visual sangat menakjubkan banyak visual art yang dimainkan. Semua ini merupakan bagian dari budaya posmo. Apa yang disebut oleh Baudrillard sebagai simulacra. Perpaduan antara kultur dan alamiah (nature), organic dan non organic, menjadi kabur (blur). 


\section{KESIMPULAN}

Dalam film ini, saya melihat apa yang dikatakan oleh Baudrillard dan Dona Haraway terlihat dalam film ini. Bukan karena realitas dalam film yang kita tonton adalah nyata, tetapi lebih pada hubungan kita dengan bentuk media tersebut (film). Dengan kata lain teori dari Haraway dan Baudrillard dalam teks visual (visual text) adalah realisasi dari teori itu (dalam dunia nyata).

Dimana dalam dunia nyata sebanyak visual teks tersebut sebagai visual teks dalam dunia nyata. (http://www.cyberartsweb.org/cpace/cyborg/film/rosenthal.html)

Budrillard menyebutkan power atau kekuasaan sebagai produk dari konsumsi massa yakni permintaan dan penyediaan (supply dan demand). Masyarakat modern memperlakukan power atau kekuasaan ini sebagai produk. Merujuk pada Baudrillard, power menjadi materi dari simulasi.

Dalam film ini dilihat bagimana teks diproduksi secara visual dan memiliki power atau kekuasaan untuk membawa orang yang menonton pada hal-hal yang futuristic, dimana dunia yang direpresentasikan sebagai urban dystopian techno.

\section{DAFTAR PUSTAKA}

Adian, Donny Gahral. 2006. Percik Pemikiran Kontemporer : Sebuah Pengantar Komprehensif. Yogyakarta: Jalasutra

Appignanesi, R., Garrat, C., Sardar, Z., \& Curry, P. 1998. Mengenal Posmodernisme: for begginers Bandung: Penerbit Mizan.

Effendy, Onong Uchjana. 2003. Ilmu, Teori dan Filsafat Komunikasi. Bandung: PT. Citra Aditya Bakti

http://en.wikipedia.org/wiki/Artificial_intelligence

http://en.wikipedia.org/wiki/John_McCarthy_\%28computer_scientist\%29

http://www.cyberartsweb.org/cpace/cyborg/film/rosenthal.html

http://www.cyberartsweb.org/cpace/cyborg/film/schwartz.html

http://www.cyberartsweb.org/cpace/cyborg/haraway/definition.html

http://www.cyberartsweb.org/cpace/cyborg/haraway/definition.html

Strinati, Dominic. 2000. Popular Culture: Pengantar Menuju Teori Budaya Populer, Bentang

Sumarno, Marselli. 2007. Dasar-dasar Apresiasi Film. 1996 Jakarta: Gramedia Widiasarana Indonesia 